\title{
Perancangan Media Kampanye Komunikasi Persuasif Dampak Pernikahan Dini Di Lombok Barat
}

\author{
I Nyoman Miyarta Yasa M.I.Kom ${ }^{1}$ \\ ${ }^{1)}$ Dosen Program Studi Desain Komunikasi Visual Universitas Bumigora Mataram \\ Jl. Ismail Marzuki Mataram, Telp (0370) - 634498 \\ ${ }^{1}$ Miyarta.yasa@universitasbumigora.ac.id
}

\begin{abstract}
ABSTRAK
Pernikahan indentik dengan kebahagiaan, setiap pasangan yang menjalani pernikahan berharap pernikahanya berjalan dengan baik. Untuk mencapai hal itu di perlukan kesiapan, baik dari segi kedewasaan berfikir dan finansial. Usia yang baik menurut para ahli, seseorang untuk menikah adalah 25 tahun untuk laki laki dan 21 tahun untuk wanita. Namun sayangnya banyak di masyarakat pernikahan terjadi di usia yang masih sangat muda, yang sering kita sebut pernikahan dini. Berdasarkan Badan Kependudukan dan Keluarga Berencana Nasional (BKKBN) angka perkawinan usia anak (18 tahun kebawah) di Indonesia makin meningkat. pernikahan dini terjadi biasanya bukan berdasarkan pertimbangan-pertimbangan yang matang, tetapi lebih didominasi oleh kebutuhan pribadi, faktor ekonomi keluarga, faktor pendidikan, hamil di luar nikah, faktor adat turun-temurun, dan faktor kejiwaan dari remaja. Komunikasi persuasif adalah salah satu metode komunikasi yang efektif untuk mempengaruhi seseorang untuk mengikuti ajakan komunikator. Dalam komunikasi persuasif media sangat di perlukan. media video di gunakan dalam komunikasi persuasif pada penelitian ini yang di harapkan mampu mempengaruhi masyarakat untuk menekan jumlah pernikahan di bawah umur. metode pengumpulan data dalam hal ini mengunakan metode Design Thingking. perancangan video iklan layanan masyarakat tentang resiko pernikahan dini di Lombok barat bersifat Soft Sell yaitu konsep menyampaikan isi pesan secara tidak langsung kepada target audiens yang dituju, dan juga memiliki konsep komedi atau bergenre komedi didalamnya. Konsep yang digunakan intuk mempengaruhi audien antara lain dari pemilihian warna, font dan juga setiap adegan dalam video. Untuk warna sendiri penulis mengguanakan warna-warna yang cerah, ceria dan menyenangkan, juga pemilihan untuk font yang terlihat santai dan ringan. sehingga iklan layanan masyarakat ini mudah untuk diingat serta dapat mempengaruhi target audiens mengikuti saran dalam video kampanye.
\end{abstract}

Kata kunci : kampanye, komunikasi persuasif, pernikahan dini

\begin{abstract}
ABSRACT
Marriage is identical with happiness, every couple who goes through marriage hopes that their marriage will go well. To achieve this requires readiness, both in terms of thinking and financial maturity. A good age according to experts, a person to get married is 25 years for men and 21 years for women. But unfortunately many in the marriage community occur at a very young age, which we often call early marriage. . Based on the National Population and Family Planning Agency (BKKBN) the number of child marriages (18 years and under) in Indonesia is increasing. Early marriages occur usually not based on mature considerations, but are more dominated by personal needs, family economic factors, educational factors, hereditary adat factors, and mental factors of adolescents. Persuasive communication is one of the effective communication methods to influence someone in this case persuasive communication with video media is expected to be able to influence the public to suppress underage marriages. Data collection methods in this case use the Design Thingking method. the design of public service video advertisements about the risk of early marriage in West Lombok is Soft Sell, namely the concept of conveying the contents of messages indirectly to the intended target audience, and also having a comedy or comedy genre concept in it. The concepts used to influence the audience include the choice of color, font and also every scene in the video. For the color itself the authors use bright colors, cheerful and pleasant, also the selection of fonts that look relaxed and light. so this public service ad is easy to remember and influences the target audience following the advice in the campaign video.
\end{abstract}

Keywords: campaign, persuasive communication, early marriage.

\section{PENDAHULUAN}

Setiap tahun jumlah penduduk Indonesia mengalami peningkatan. Menurut Badan Kependudukan dan Keluarga Berencana Nasional (BKKBN) pertumbuhan penduduk di
Indonesia masih tinggi. Hingga saat ini tingkat pertumbuhan penduduk di Indoneisa masih mencapai 1,49 persen atau sekitar empat juta pertahun. Jumlah penduduk di Indonesia diperkirakan mencampai hampir 262 juta jiwa pada tahun 2017 dan jumlah tersebut terus 


\section{SASAK: DESAIN VISUAL DAN KOMUNIKASI}

Vol. 01 No. 2 (November) 2019, Hal 83-91, e-ISSN. 2685-4120

https://journal.universitasbumigora.ac.id/index.php/sasak

meningkat pada tahun 2018 yang mencapai 265 juta jiwa penduduk berdasarkan proyeksi Badan Perencanaan Pembangunan Nasional (Bappenas) 2013. Tingginya pertumbuhan penduduk di Indonesia di karenakan masih tingginya angka kelahiran dan pernikahan. Berdasarkan hasil survei Indikator Kinerja Rencana Pembangunan Jangka Menengah Nasional (RPJM) Program Kependudukan dan Keluarga Berencana tahun 2015, sebanyak 19,2 persen respon remaja wanita merencankan menikah di bawah umur 22 tahun. Sementara untuk remaja pria sebesar 46,2 persen merencankan menikah umur 20-25 tahun. Usia ideal menikah menurut BKKBN untuk perempuan minimal 21 tahun dan untuk lakilaki minimal 25 tahun [1].

Akhir-akhir ini pernikahan dini sering terjadi di berbagai wilayah di Indonesia, salah satunya adalah dipulau Lombok, Nusa Tenggara Barat. Di Lombok sendiri pernikahan dini banyak terjadi dan menjadi sebuah hal yang biasa dilakukan oleh setiap anak yang baru mulai tumbuh remaja. Menurut data BKKBN, angka pernikahan dini pada tahun 2015 di NTB masih tinggi sebanyak 67,15 persen sampai 63,28 persen. Pernikahan dini terjadi di berbagai wilayah di Lombok terutama di wilayah pedesaan-pedesaan. Di Kabupaten Lombok Barat sendiri pernikahan anak di bawah umur masih cukup tinggi, tahun 2017 menurut Badan Pusat Statistik (BPS) Kabupaten Lombok Barat dari data Kementrian Agama Kabupaten Lombok Barat usia pernikahan dini remaja laki-laki dibawah umur 21 kebawah sebanyak 3.728, dan remaja perempuan di bawah umur 21 kebawah sebanyak 2.105. Di Kabupaten Lombok Barat sendiri memiliki 10 Kecamatan yang dimana dari 10 Kecamatan menyumbang angka pernikahan yang tinggi. Di sepuluh kecamatan di Kabupaten Lombok Barat sekurangkurangnya menyumbang angka pernikahan dibawah umur sebanyak 10\%. Daerah terbanyak terjadinya pernikahan dini di Kabupaten Lombok Barat adalah di Desa Gerung dengan jumlah pernikahan dini dibawah kisaran umur 19 tahun sebanyak 349 dan umur 19-21 sebanyak 246 untuk laki-laki jumlah keseluruhan sebanyak 595 remaja, dan untuk perempuan kisaran umur dibawah 19 tahun sebanyak 192 dan umur 19-21 sebanyak 246 dan jumlah keseluruhan sebanyak 438 remaja. Permasalahan seperti ini sangat butuh perhatian dari pemerintah dan salah satu upaya dalam menguranginya adalah melalui edukasi atau himbauan yang berbentuk iklan layanan masyarakat.

Iklan layanan masyarakat adalah pesan yang diiklankan yang bersifat mendidik dan

memberikan informasi kepada masyarakat luas. Iklan layanan masyarakat yang biasanya dikenal dengan sebutan ILM menjadi salah satu cara untuk menggerakkan atau menimbulkan solidaritas masyarakat luas dalam menghadapi berbagai permasalahan yang terjadi dimasyarakat. Berdasarkan Undang-Undang 32 tahun 2002 tentang penyiaran disebutkan bahwa siaran iklan layanan masyarakat adalah siaran iklan non komersial yang disiarkan melalui siaran radio atau televisi dengan tujuan memperkenalkan, memasyarakatkan dan mempromosikan gagasan, cita-cita, anjuran, dan pesan-pesan lainnya kepada masyarakat untuk mempengaruhi khalayak agar berbuat dan bertingkah laku sesuai dengan pesan iklan tersebut. Iklan Layanan Masyarakat menurut Persatuan Perusahaan Periklanan Indonesia (PPPI) merupakan sebuah informasi untuk keperluan publik yang menyangkut berbagai gagasan atau wacana yang bertujuan untuk merubah, memperbaiki atau untuk membuat prilaku atau sikap masyarakat luasmenjadi lebih baik. Menurut Putra [2] memberi pendapat bahwa ILM pada dasarnya adalah alat atau media dalam penyampaian pesan atau informasi sosial kepada khalayak luas. Media atau alat seperti ini sering kali digunakan oleh pemerintah atau instansi tertentu dalam penyampaian gagasan, ide bahkan program-programnya. Sebagai media yang bergerak dalam bidang sosial, Iklan layanan masyarakat biasanya berisi pesan tentang kesadaran nasional dan lingkungan atau peristiwa yang ada ditengah masyarakat. Iklan layanan masyarakat harus tepat kepada target atau sasaran yang ingin dituju, karena pada dasarnya ILM bertujuan untuk merubah kesadaran dan pola pikir masyarakat luas akan pemecahan suatu masalah sosial yang aktual.

Melihat dari permasalahan diatas angka pernikahan dini di kabupaten Lombok Barat masih tinggi, itu dikarenakan oleh beberapa faktor dan kurangnya edukasi terhadap pernikahan dini. Dalam hal untuk mengedukasi remaja tentang resiko dari pernikahan dini, diperlukannya sebuah usaha bersama terutama dari pemerintah, untuk memberi pengetahuan

kepada remaja tentang resiko-resiko yang bisa dialami jika terjadinya pernikahan dini. Salah satunya dengan membuat sebuah himbauan atau informasi melalui sebuah iklan layanan masyarakat yang diharapkan dapat mengedukasi para remaja tentang resiko dari pernikahan dini. 


\section{a. Rumusan Masalah}

Dari permasalahan diatas penulis dapat menentukan rumusan masalah yaitu:

Bagaimana merancang media kampanye komunikasi persuasive dampak Pernikahan Dini di Kabupaten Lombok Barat?

b. Batasan Masalah

Perancangan kampanye komunikasi persuasif sebagai media edukasi remaja di Kabupaten Lombok Barat tentang dampak dari pernikahan dini.

$\square$ Kampanye komunikasi persuasive akan berbentuk video yang berdurasi 30 detik-1 menit

Pengeditan menggunakan software Adobe Premiere Pro CS6

c. Tujuan

Terciptanya sebuah video iklan layanan masyarakat sebagai kampanye tentang resiko pernikahan dini dengan komunikasi persuasive sebagai alat edukasi terhadap remaja-remaja yang ada di Kabupaten Lombok Barat.

d. Manfaat

\section{Secara Teoritis}

Perancangan iklan layanan masyarakat yang bersifat Soft Sell dalam penyampaian pesan diharapkan dapat menjadi solusi dalam penyampaian informasi secara tepat dan jelas, dan diharapkan dapat dijadikan sebagai referensi untuk kasus atau masalah

yang sama sehingga terciptanya pemahaman yang lebih mendalam tentang pernikahan dini untuk kedepannya.

Secara Praktis

Terbentuknya pola pikir remaja untuk berfikir lebih matang sebelum membangun rumah tangga. Dan terciptanya kesadaran remaja tentang resiko dari pernikahan dini.

UntukKhalayakUmum:

Meningkatnya pengetahuan masyarakat luas terhadap pernikahan dini juga sebagai bahan atau materi pembelajaran dalam mendidik.

$\square$ Untuk Instansi: Sebagai media pendukung dalam program-program sosialisasi dan sebagai bahan materi atau reprensi dalam pembuatan program-program.

e. Definisi Oprasional

Pernikahan dini yang dalam bahasa sasak "Merariq Kodeq" merupakan sebuah pernikahan yang terjadi dibawah umur dan belum adanya persiapan yang matang dari remaja-remaja yang menikah. Pernikahan dini yang dilakukan sangatlah mempunyai resiko dari segi kesehatan, psikologis, dan sosial. Dari segi kesehatan sangat beresiko bagi perempuan karna organ-organ belum siap atau matang, dari segi psikologis dan sosial belum siapnya emosi dan cara berfikir dalam membangun rumah tangga dan dalam masyarakat. Dalam hal ini sebuah perancangan iklan layanan masyarakat berupa kampanye komunikasi persuasif tentang pernikahan dini yang ada di Lombok barat merupakan sebuah solusi dalam mengedukasi masyarakat terutama remaja-remaja supaya dapat lebih mengetahui resiko-resiko yang dapat terjadi bila dilakukannya pernikahan dibawah umur. Iklan layanan masyarakat (ILM) yaitu sebuah iklan atau informasi yang disampaikan berisi permasalahanpermasalahan dalam masyarakat dan bersifat nonprofit (tidak mementingkan keuntungan). Maka dari itu penulis juga menginginkan sebuah rancangan iklan layanan masyarakat yang bersifat soft sell dan bisa untuk menjadi alat dalam penyampaian informasi yang baik, efektif dan tepat sasaran kepada target audiens.

\section{LANDASAN TEORI}

A. Kampanye dan komunikasi persuasif

Kampanye adalah sebuah tindakan dan usaha yang bertujuan mendapatkan dukungan, usaha kampanye bisa dilakukan oleh peorangan atau sekelompok orang yang terorganisir untuk melakukan pencapaian pengambilan keputusan di dalam suatu kelompok, kampanye biasa juga di gunakan untuk mempengaruhi, penghambatan, pembelokan dan bersifat ajakan.

Erwin P. Betinghaus dalam bukunya yang berjudul "Persuasif Communication" tahun 1973, halaman 10 . Di sana dijelaskan bahwa komunikasi persuasif ini dapat mempengaruhi pemikiran dan perbuatan seseorang, hubungan aktivitas antara pembicara dan pendengar dimana pembicara berusaha mempengaruhi tingkah laku pendengar melalui perantara pendengaran dan penglihatan. Bentuk-bentuk komunikasi persuasif antara lain :

1. Iklan

iklan sendiri merupakan bagian dari jenis promosi. Sehingga, iklan merupakan bagian kecil dari aktivitas promosi yang lebih luas. 


\section{SASAK: DESAIN VISUAL DAN KOMUNIKASI}

Vol. 01 No. 2 (November) 2019, Hal 83-91, e-ISSN. 2685-4120

https://journal.universitasbumigora.ac.id/index.php/sasak

Iklan inilah yang menggunakan komunikasi persuasif sebagai bahasa mengajak para calon pelanggan untuk menggunakan produknya ini berlaku pada sebuah badan atau usaha yang tujuanya memperoleh keuntungan. Ada jenis iklan lain yang tujuanya mempengaruhi audien untuk mengikuti ajakan komunikator namun hanya sebagai media edukasi atau ajakan mengikuti program pemerintah, tanpa tujuan untuk memperoleh keuntungan

2. Dakwah, Dakwah merupakan aktivitas yang bersifat menyerukan seperti layaknya orasi namun sifatnya mengajak orang-orang untuk berjalan ke jalan yang benar. Sehingga, aktivitas ini memerlukan bahasa persuasif yang dapat membuat orang yang mendengar pesan tersebut menjadi ikut pengaruh dalam bahasa dan kata-kata yang disampaikan. Aktivtas inilah yang kerap kali dilupakan kalau menggunakan persuasif tapi bukan dogmatis.

3. Pamflet, Pamflet merupakan bentuk komunikasi persuasif secara verbal yang berbentuk tulisan. Bentuk ini sebenarnya masuk ke dalam kategori iklan. Namun, pada umumnya di jaman sekarang menjadi paradigma dalam bentuk audio visual. Di dalam pamflet pastinya berunsur iklan yang bersifat mengajak, sehingga pamflet merupakan salah satu bentuk komunikasi persuasif.

\section{B. Iklan Layanan Masyarakat}

Iklan merupakan semua bentuk penyediaan dan promosi secara nonpribadi mulai dari ide barang dan pelayanan yang ditanggung oleh sponsor. Berdasarkan Undang-Undang No.32 Tahun 2002 tentang penyiaran bab 1 pasall (5) menyebutkan bahwa siaran iklan adalah siaran informasi yang bersifat komersial dan layanan masyarakat tentang tersedinya jasa, barang, dan gagasan yang dapat di manfaatkan oleh masyarakat luas dengan atau tanpa imbalan kepada lembaga peyiaran yang bersangkutan.

Berdasarkan Undang-Undang 32 tahun 2002 tentang penyiaran disebutkan bahwa siaran iklan layanan masyarakat adalah siaran iklan non komersial yang disiarkan melalui siaran radio atau televisi dengan tujuan memperkenalkan, memasyarakatkan dan mempromosikan gagasan, cita-cita, anjuran, dan pesan-pesan lainnya kepada masyarakat untuk mempengaruhi khalayak agar berbuat dan bertingkah laku sesuai dengan pesan iklan tersebut. Iklan Layanan Masyarakat menurut Persatuan Perusahaan Periklanan Indonesia (PPPI) merupakan sebuah informasi untuk keperluan publik yang menyangkut berbagai gagasan atau wacana yang bertujuan untuk merubah, memperbaiki atau untuk membuat prilaku atau sikap masyarakat luas menjadi lebih baik.

Putra memberi pendapat bahwa ILM pada dasarnya adalah alat atau media dalam penyampaian pesan atau informasi sosial kepada khalayak luas. Media atau alat seperti ini sering kali digunakan oleh pemerintah atau instansi tertentu dalam penyampaian gagasan, ide bahkan program-programnya. Sebagai media yang bergerak dalam bidang sosial, Iklan layanan masyarakat biasanya berisi pesan tentang kesadaran nasional dan lingkungan atau peristiwa yang ada ditengah masyarakat. Iklan layanan masyarakat harus tepat kepada target atau sasaran yang ingin dituju, karena pada dasarnya ILM bertujuan untuk merubah kesadaran dan pola pikir masyarakat luas akan pemecahan suatu masalah sosial yang aktual [2].

Terdapat lima unsur pemasaran sosial berdasarkan Kotler dan Roberto, yaitu:

1. Cause yaitu sasaran sosial yang diyakini sebagai sebuah cara untuk meraih perubahan dan dapat memberikan jawaban tentang permasalahan sosial disekitar.

2. Change agent ialah individu,kelompok, atau organisasi yang mencoba untuk melakukan perubahan sosial dengan melalui kampanye.

3. Target adopter merupakan sebuah kelompok, individu atau semua populasi yang merupakan target dari sebuah perubahan.

4. Channelsadalah jalan atau alur komunikasi dan distribusi yang dipergunakan dalam menyampaikan atau mempromosikan produk sosialnya.

5. Change strategy panduan atau pedoaman yang digunakan oleh sesorang untuk mengubah sikap dan prilaku dari individu, kelompok atau organasasi sasaran.

\section{B. Media}

Dari pendapat Hasan Alwi [3], berpendapat bahwa media merupakan alat atau perantara yang digunakan untuk menyampaikan pesan atau informasi untuk berkomunikasi seperti koran, radio, televisi, majalah, film, foster, brosur, baliho dan spanduk yang terletak di antara kedua belah 


\section{SASAK: DESAIN VISUAL DAN KOMUNIKASI}

Vol. 01 No. 2 (November) 2019, Hal 83-91, e-ISSN. 2685-4120

https://journal.universitasbumigora.ac.id/index.php/sasak

pihak. Ahli lain juga memberi pandangan tentang media, (Ananda, 1978:10) mengatakan dasar pemikirin dalam memilih media yaitu dapat mencakup masayarakat luas, jumlah informasi yang dapat ditampung oleh media, dan target audiens.

Secara umum pelaku periklanan membagi media menjadi tiga bagian, yaitu:

- Media Lini Atas (above the line) Merupakan media yang yang sangat mencakup masyarakat luas dan memerlukan media luar raung seperti iklan surat kabar, iklan majalah, poster dan sebagainya. Juga menggunakan media elektronik baik media audio maupun audio visual seperti radio, film, televisi, video, dan lainnya.

- Media Lini Bawah (below the line) Yaitu media yang tidak perlumemerlukan ruang yang luas atau terbuka yang memerlukan pemasangan iklan karna media yang sering digunakan seperti direct mail, pameran, kalender, agenda, dan media souvenir.

- Media Lini Tengah (through the line) Adalah media yang baru munculdan jarang digunakan, media ini adalah media yang berada diantara media lini atas dan media lini bawah. Selain pemilihan media yang tepat, penulis juga memilih alat dalam penggunaan untuk pengeditan ILM yang akan dibuat.

C. Video

Kata video berasal dari bahasa latin yaitu dari kata vidi atau visum yang merupakan proses melihat atau memiliki kemampuan untuk melihat. Video memiliki fasilitas yang berbeda dengan media lainnya karena mempunyai atau menyediakan satu cara penyaluran informasi yang amat menarik dan langsung (live). Video juga

termasuk media yang memiliki daya tarik tersendiri jika dibandingkan dengan media lain seperti grafik, audio dan sebagainya.

Munir [4], berpendapat bahwa Video merupakan sebuah media yang mempunyai kelebihan dalam hal merekam, menagkap, mengolah, dan penyimpan gambar juga berfungsi sebagai pemindahan, dan perekonstruksian urutan gambar diam dengan menyajikan adegan-adegan dalam gerak secara elektronik. Video menyediakan sumber daya yang kaya dan hidup bagi aplikasi multimedia dan pada umumnya video juga bisa disebut dengan bentuk gambar yang bergerak.

\section{Pernikahan}

Dalam agama menikah merupakan suatu proses pembentukan perjanjian untuk menyatukan antara pria dan prempuan agar menghalalkan hubungan badan dari pasangan suami istri sehingga terbentuknya kehidupan berkeluarga yang bahagia dan diliputi rasa cinta, saying, nyaman dan tentram dengan cara-cara yang di kehendaki oleh Allah SWT.

Menurut Soemiyati [5], Muhammad Abu Zahra mengartikan bahwa pernikahan merupakan sebuah akad yang mengesahkan sebagai cara bersenangsenang dari kedua pihak calon pengantin dengan cara-cara yang telah diSyari'atkan. UndangUndang No.1 Tahun 1974 menjelaskan bahwa perkawinan ialah ikatan lahir batin antara seorang pria dan seorang wanita sebagai suami-istri dengan tujuan membentuk rumah tangga yang bahagia dan kekal berdasarkan ketuhanan Yang Maha Esa.

\section{E. Pernikahan Dini}

Pernikahan dini merupakan lembaga besar yang menyatukan laki-laki dan perempuan yang berusia dibawah umur dalam sebuah bentuk rumah tangga. Dalam Undang-Undang perkawinan sendiri pernikahan dini sudah diatur dalam bab 11 pasal 7 ayat 1 yang menyatakan bahwa perkawinan hanya dapat diizinkan jika pihak pria sudah mencapai usia 19 tahun dan pihak wanita sudah mencapai usia 16 tahun.

Pernikahan dini secara umum yaitu pernikahan yang dilakukan oleh laki-laki dan perempuan yang masih dibawah umur. Menurut (Nukman, 2009) perkawinan dibawah umur merupakan pernikahan yang sejatinya belum siap dilaksanakan karena belum ada kesiapan dan kematangan dari kedua calon pengantin dalam menjalankan dan membangun rumah tangga. Dalam adat Sasak sendiri pernikahan dini dalam bahasa Sasak disebut "merari' kodeq", kedua kata tersebut memiliki arti tersendiri "merari" yang artinya pernikahan dan "kodeq" yang artinya kecil. Kata "merari' kodeq" yang berarti pernikahan yang dilakukan pada saat usia masih kecil dan belum siap untuk membangun rumah tangga. Berdasarkan BKKBN pernikahan dini bisa terjadi karena disebabkan atau didorong oleh beberapa faktor seperti faktor sosial, ekonomi, pendidikan, budaya, diri sendiri, orang tua, dan tempat tinggal. F. Pernikahan di Lombok

Menikah dalam budaya Sasak, Lombok. Pernikahan dalam budaya Sasak biasa disebut dengan kata Merari' secara etimelogi kata Merari' berasal dari bahasa Sasak yang diadaptasi dari kata "lari". Seperti Merari'an yaitu Melai'an yang maknanya melarikan. Kawin lari atau biasa disebut "paling nine" yang artinya mencuri calon istri merupakan proses adat dalam melakukan pernikahan yang sampai saat ini masih digunakan oleh masyarakat Lombok (Salam, 1992:22). Menurut (Tim Departemen Pendidikan dan 
Kebudayaan, 1995:33) menyebutkan bahwa pelarian adalah cara untuk membebaskan calon wanita dari ikatan orangtua dan juga keluarganya.Merari' juga merupakan sebuah tradisi yang sudah sangat melekat pada masyarakat suku Sasak sendiri dan menjadi sebuah bentuk dari kejantanan seorang lakilaki sasak karena telah berhasil mengambil (melarikan atau mencuri) seorang gadis yang sudah lama didambakan.

Kabupaten Lombok Barat dengan ibu kota kabupatenya yaitu Gerung merupakan salah satu daerah denga persentase pernikahan dini yang cukup besar berdasarkan data BKKBN.

\section{METODOLOGI PENELITIAN}

Dalam pengumpulan data penulis menggunakan metode pengumpulan data Design Thingking. Yaitu sebuah metode yang digunakan untuk mewujudkan atau membuat konsep kreatif yang sesuai dengan konsep perancangan iklan layanan masyarakat (ILM), Dalsgaard [6]. Penggunaan metode penelitian design thingking dalam pengumpulan data merupakan langkah atau cara penulis dalam mendapatkan atau mengumpulkan data penelitian yang dimana nantinya akan menjadi acuan dalam perancangan iklan layanan masyarakat. Metode design thingking juga merupakan metode yang memiliki alur yang sesuai dengan proses dan konsep penulis dalam pengumpulan data dan yang akan menjadi acuan pemecahan masalah dalam merancang iklan layanan masyarakat. Untuk menganalisis data menggunakan metode:

- $\quad$ Metode kualitatif yang dimana data yang didapatkan kemudian diuraikan berupa teks. Analisis Kualitatif adalah sebuah data yang dipergunakan sebagai cara untuk meneliti, mengungkapkan, memvisualisasikan, dan menerengkan kelebihan dari pengaruh lingkungan

sosial yang tidak bisa dianalisis dengan menggunakan metode kuantitatif Lexy J.Moleong [7].

- Penulis juga menggunakan analisis data $5 \mathrm{~W}+1 \mathrm{H}$ dalam pengolahan data yang akan digunakan sebagai perancangan iklan layanan masyarakat, yang merupakan sebuah metode berbentuk pertanyaan yang akan menjadi landasan pemecahan masalah yang dihadapi penulis.

\section{VISUALISASI}

\section{A. Konsep Media}

Dalam perancangan iklan layanan masyarakat tentang pernikahan di kabupaten Lombok barat penulis sendiri menggunakan media video yang berbentuk video iklan yang bersifat soft sell tentang edukasi resiko dari pernikahan dini yang diharapkan dapat menjadi media edukasi terhadap remaja-remaja di Lombok barat. video iklan yang akan dibuat menggunakan konsep yang berbeda dari video iklan lainnya. Video tentang pernikahan dini yang sudah ada disosial media salah satunya di youtube. Penulis menggunakan konsep komedi atau video iklan yang bergenre komedi yang ringan dan menarik yang bertujuan untuk menarik target audiens.

B. Strategi Media

a. Khalayak Sasaran

Pemilihan target audiens sebagai penerima pesan dilakukan oleh penulis yang dilihat dari beberapa aspek dan unsur tertentu yang berkaitan dengan target audiens. Itu semua penulis lakukan supaya pesan atau informasi yang ingin disampaikan bisa efektif dan tepat sasaran. Dalam hal ini penulis memilih target audiens remaja yang berusia 15-18 tahun yang berdasarkan dari aspek demografis, goegrafis, dan psikografis.

b. Pemilihan Media

Dalam penyelesaian masalah diperlukannya media yang tepat dan efektif, penulis sendiri menentukan media video berbentuk video iklan sebagai media utama dikarenakan media video lebih menarik dan dapat menyampaikan informasi secara jelas karna terdapat unsur audio dan visual didalamnya. Dewasa ini remaja-remaja di Kabupaten Lombok Barat terutama di Desa Gerung mengetahui atau mengenal dengan kemajuan zaman dan teknologi yang pesat sehingga rata-rata remaja memiliki smartphone. Penulis juga sedikit melakukan survey dengan mewancarai beberapa remajaremaja di Desa Gerung tentang lebih tertarik dengan video atau dengan gambar, dari hasil survei empat dari lima remaja lebih tertarik dengan video.

C. Tipografi

Pemilihan jenis huruf sangat berpengaruh dalam penyampaian pesan dan isi pesan karena huruf menjadi bagian penting dalam sebuah pesan. Untuk menciptakan iklan layanan masyarakat yang terkesan komedi, penulis memilih jenis huruf sans serif yang dimana jenis huruf ini adalah jenis huruf tanpa kaki yang memiliki sifat yang tegas, jelas untuk dibaca, ringan dan juga santai. Jenis huruf yang penulis gunakan harus 


\section{SASAK: DESAIN VISUAL DAN KOMUNIKASI}

Vol. 01 No. 2 (November) 2019, Hal 83-91, e-ISSN. 2685-4120

https://journal.universitasbumigora.ac.id/index.php/sasak

memvisualisasikan bentuk dari komedi yang ringan, tegas dan menyenangkan. Ada beberapa pilihan jenis huruf yang akan penulis gunakan dalam perancangan ILM, jenis huruf ini nantinya bisa digunakan sebagai judul, slogan dan teks dalam iklan video itu sendiri.

\section{Camping Holiday DEMO \\ Pilkius Romeus \\ Hangyaboly \\ FUNHOUSE}

Gambar 1. Tipografi

Sumber: fontspace.com

\section{Tone warna}

Warna menjadi unsur pendukung yang penting dalam perancangan sebuah video iklan karena dapat memvisualisasikan sebuah

suasana atau isi pesan dalam film pendek. Dalam perancangan video iklan tentang pernikahan dini yang ada di Kecamatan Gerung dengan tetap menggunakan konsep komedi dalam penyampaian pesannya, penulis memilih warna-warna yang

memvisualisasikan bentuk dari kesenangan, ringan, lucu, dan santai. Tone warna yang dipilih merupakan warna-warna yang terang dan jelas untuk dilihat. Dibawah ini beberapa contoh pemilihan warna oleh penulis yang diharpkan dapat menciptakan bentuk pesan yang ingin dibuat.

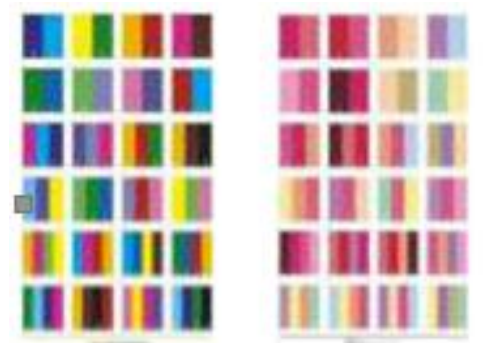

\section{Gambar 2. Tone Warna} Sumber: Pinterest

Sebelum proses perancangan untuk shooting video iklan layanan masyarakat, penulis membuat rancangan kasar berbentuk mind map atau peta pikiran, yang dimana dari mind map yang dibuat akan menjadi dasar rancangan dalam video iklan layanan masyarakat.

\section{E. Mind Map}

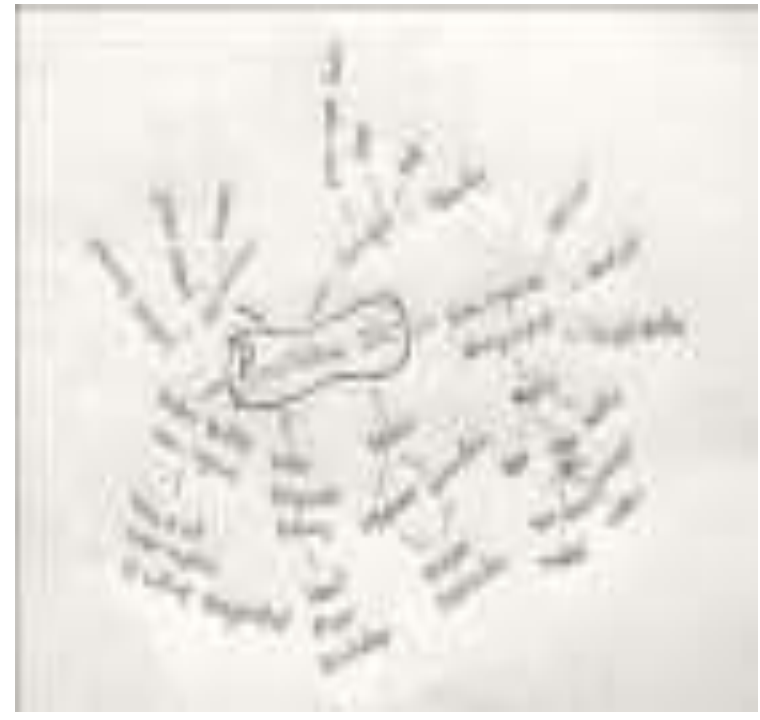

\section{F. Storyboard}

Gambar 3. Mind Mapping
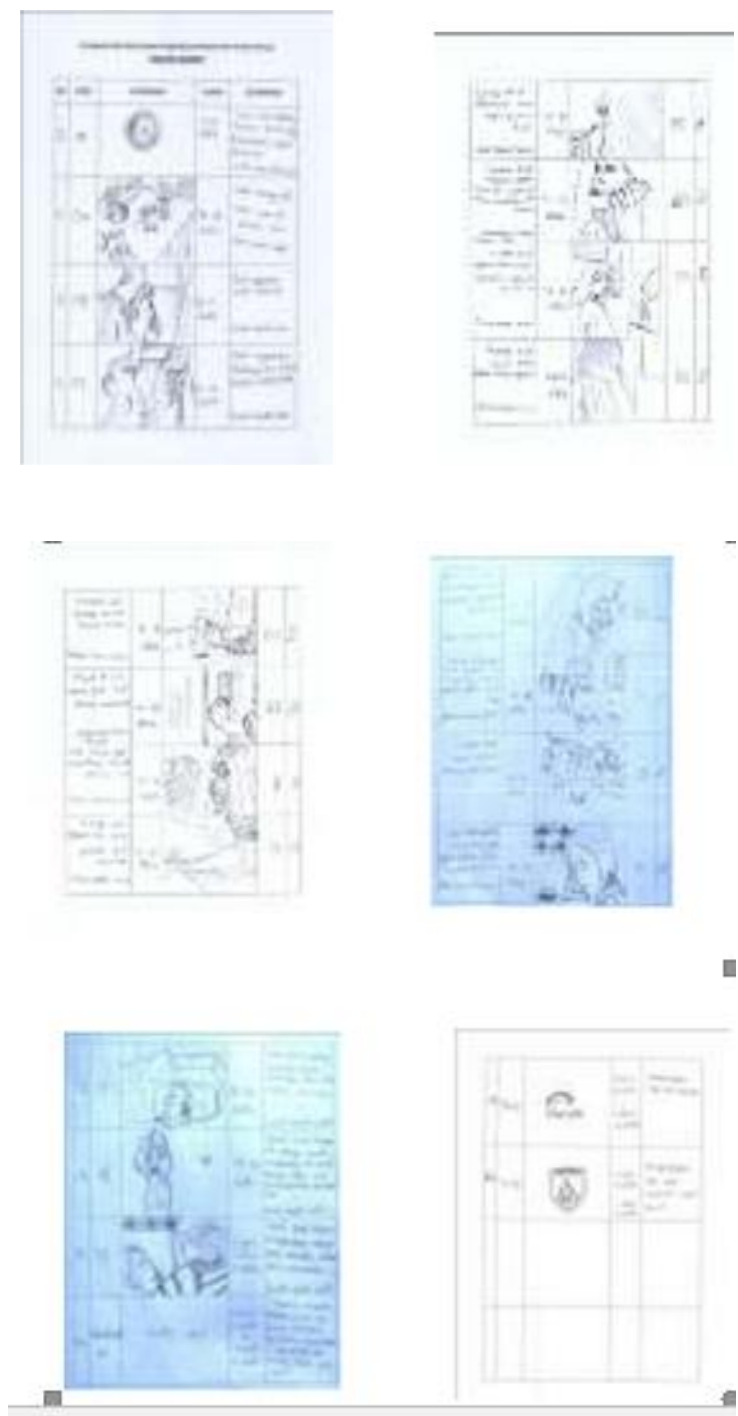

Gambar 4. Storyboard 


\section{G. Final Desain}
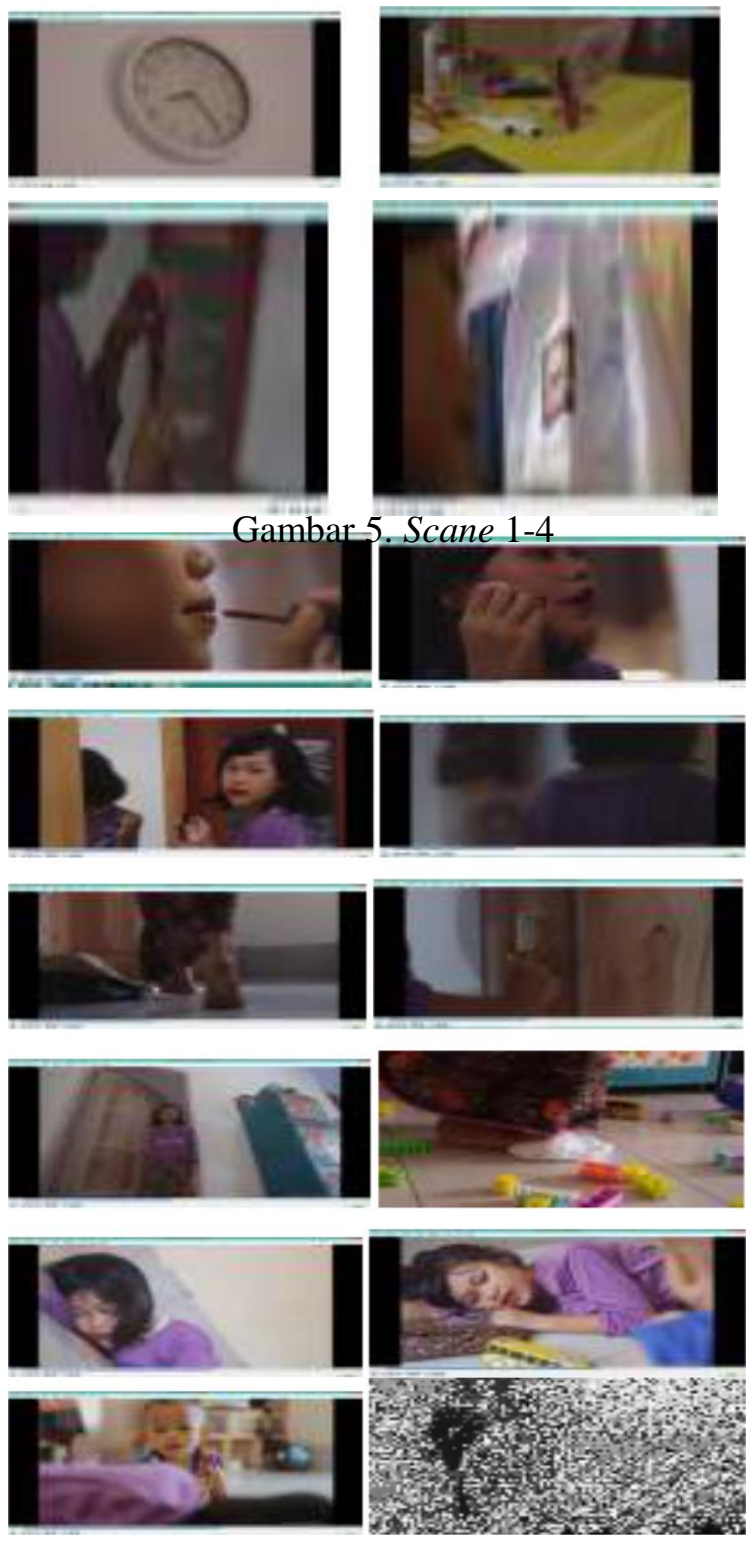

Gambar 6. Scane 5-16
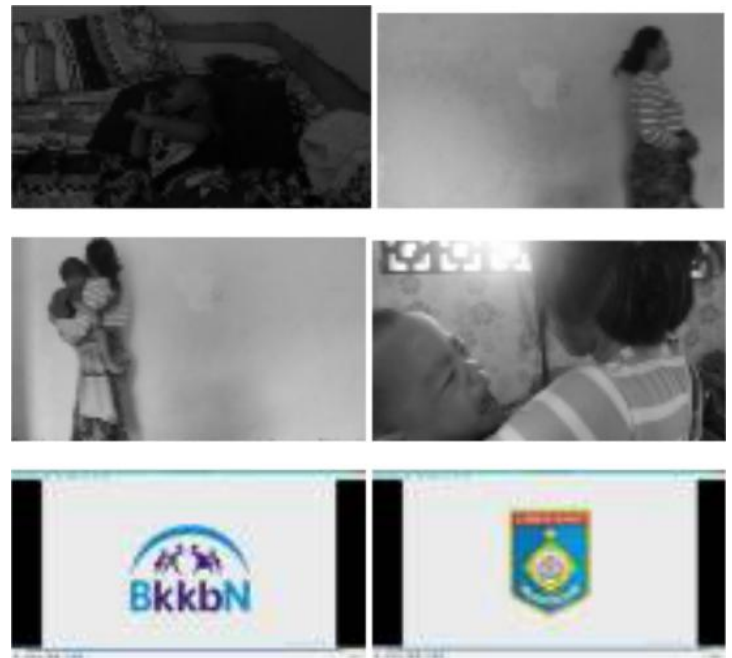

\section{Gambar 7. Scane 17-19}

\section{KESIMPULAN}

Penulis merancang sebuah video iklan layanan masyarakat dengan kampanye komunikasi persuasif tentang resiko pernikahan dini di Lombok barat. Perancangan ini didasari dari permasalahan masih tingginya angka pernikahan dini yang terjadi di Indonesia terutama di, Kabupaten Lombok Barat. Untuk pengumpulan data sendiri penulis menggunakan metode Design Thingking sebagai acuan dalam proses perancangan karena metode Design Thingking memiliki langkah-langkah atau proses yang sesuai dengan konsep penulis dalam merancang video iklan layanan masyarakat yang bersifat Soft Sell. Penulis menggunakan metode analisis data kualitatif dalam pengumpulan data dan juga analisis data $5 \mathrm{~W}+1 \mathrm{H}$ yanng dimana nantinya sebagai acuan dalam perancangan video iklan layanan masyarakat.

Konsep perancangan dalam video iklan layanan masyarakat dengan komunikasi persuasive tentang resiko pernikahan dini di Lombok Barat berupa video iklan yang bersifat Soft Sell yaitu konsep menyampaikan isi pesan secara tidak langsusng kepada target audiens yang dituju, dan juga memiliki konsep komedi atau bergenre komedi didalamnya. Konsep yang digunakan mempengaruhi dari pemilihian warna, font dan juga setiap adegan dalam video. Untuk warna sendiri penulis mengguanakan warnawarna yang cerah, ceria dan menyenangkan, juga pemilihan untuk font yang terlihat santai dan ringan. Citra visual yang ingin di ciptakan dari video iklan layanan masyarakat perikahan dini yaitu lucu atau jenaka yang ringan, yang dimana dalam penyampaian pesannya tetap menyampaikan isi pesan namun dengan jalan cerita atau bentuk dalam video iklan yang lucu atau jenaka, sehingga penulis ingin membuat iklan layanan masyarakat yang mudah untuk diingat serta menarik oleh target audiens.

\section{REFERENSI}

[1] "Data BKKBN," 2019. [Online]. Available: https://www.bkkbn.go.id. [Accessed: 20-Jan2019].

[2] D. F. P. Putra, Perancangan Iklan Layanan Masyarakat tentang Perlindungan Satwa Liar Indonesia. Malang: Universitas Negeri Malang. Fakultas Sastra. Jurusan Seni dan Desain. Program Studi Desain Komunikasi Visual., 2010.

[3] H. Alwi, Kamus Besar Bahasa Indonesia. Jakarta: Balai Pustaka, 2002.

[4] Munir, Multimedia : Konsep \& Aplikasi dalam Pendidikan. Bandung: Alfabeta, 2012. 
Vol. 01 No. 2 (November) 2019, Hal 83-91, e-ISSN. 2685-4120

https://journal.universitasbumigora.ac.id/index.php/sasak

[5] N. Soemiati., Hubungan Perkawinan Islam dan Undang-Undang Perkawinan (Undang-Undang No 1 Tahun 1974 Tentang Perkawinan). Yogyakarta: Liberty, 1982.

[6] P. Dalsgaard, Pragmatism and design Thingking. International Journal of Design. 2014.

[7] L. J. Moleong., Metodologi penelitian kualitatif. Bandung: Remaja Rosdakarya., 2005.

[8] Rahman M, Fachrir. 2013. Pernikahan di Nusat Tenggara Barat:Antara Islam dan Tradisi. Mataram : Lembaga PengkajianPublikasi Islam dan Masyarakat (LEPPIM) IAIN Mataram. 